\title{
Artikel
}

\section{Wetgeving straf- en strafprocesrecht in Aruba, Curaçao en Sint Maarten}

\author{
Mr. J.H.J. Verbaan en mr. B.A. Salverda*
}

\section{Inleiding}

In de voormalige Nederlandse Antillen en Aruba is al enige tijd een herziening gaande van het straf- en strafprocesrecht. Over deze wetgeving, zowel op het gebied van het strafrecht als het strafprocesrecht, is eerder een artikel geschreven. Daarin werd een overzicht gegeven van de toen geldende stand van zaken in de landen Aruba, Curaçao en Sint Maarten en het gebied van de openbare lichamen Bonaire, Sint Eustatius en Saba. ${ }^{1}$ Onlangs is door de commissie herziening Wetboek van Strafvordering een vernieuwd concept aangeboden aan de ministers van Justitie van Aruba, Curaçao en Sint Maarten. Dat is een signaal dat het tijd is voor een nieuw overzicht. In dit artikel wordt de huidige stand van zaken van de strafwetgeving en de wetgeving op het

Mr. J.H.J. Verbaan is werkzaam als wetenschappelijk onderzoeker bij de sectie Strafrecht van de Erasmus Universiteit Rotterdam. In die hoedanigheid maakt hij ook deel uit van het Antilliaanse projectteam van prof. De Doelder. Dit projectteam heeft bijstand verleend bij de totstandkoming van het nieuwe Wetboek van Strafrecht, alsmede de herziening van het Caribisch Wetboek van Strafvordering. Momenteel draagt hij bij aan het proces van invoering van het Wetboek van Strafvordering en bijbehorende uitvoeringswetgeving. Mr. B.A. Salverda is werkzaam als wetenschappelijk onderzoeker bij de sectie Strafrecht van de Erasmus Universiteit Rotterdam. In die hoedanigheid maakt zij ook deel uit van het Antilliaanse projectteam van prof. De Doelder. Dit projectteam heeft bijstand verleend bij de totstandkoming van het nieuwe Wetboek van Strafrecht, alsmede de herziening van het Caribisch Wetboek van Strafvordering. Momenteel draagt zij bij aan het proces van invoering van het Wetboek van Strafvordering en bijbehorende uitvoeringswetgeving. Dit artikel geeft de stand van zaken weer op het gebied van de herziening van het straf- en strafprocesrecht in de Cariben.

1. J.H.J. Verbaan \& B.A. Salverda, 'Nieuwe strafwetgeving: de stand van zaken', CJB 2014/3, p. 145-157. gebied van het strafprocesrecht weergegeven. Met name wordt stilgestaan bij het Wetboek van Strafvordering, waarbij eerst een overzicht wordt gegeven van het proces van totstandkoming. Tevens worden de voornaamste wijzigingen besproken. Tot slot wordt aandacht besteed aan een korte vergelijking met het project Modernisering van het Nederlandse Wetboek van Strafvordering.

\section{Stand van zaken Strafrecht}

Het Wetboek van Strafrecht (hierna: $\mathrm{WvSr}$ ) is in Aruba, Curaçao en Sint Maarten - voor de landen als zelfstandig samengesteld met enige onderlinge verschillen - al enige jaren van kracht. De nieuwe bepalingen van de wetboeken van strafrecht functioneren naar behoren. Er zijn tot op heden weinig juridische problemen uit voortgevloeid. Een bijzondere vermelding verdient het nieuwe artikel 1:30 WvSr, dat zowel in Aruba, Curaçao als in Sint Maarten geldt. Dit artikel bevat een bepaling die toetsing van de levenslange gevangenisstraf voorschrijft. Die bepaling vormde aanleiding om in een strafzaak door te procederen tot aan Straatsburg. ${ }^{2}$ De toetsing van de levenslange gevangenisstraf kent al een uitgebreide bespreking in andere artikelen. ${ }^{3}$ De zaak die het tot Straatsburg bracht, Murray tegen Nederland, leidde niet tot afkeuring door het Europees Hof voor de Rechten

2. HR 5 juli 2016, ECLI:NL:HR:2016:1361, NJ 2016/347, m.nt. T. Kooijmans.

3. Zie o.a. T. de Bont \& S. Meijer, 'Perspectief voor levenslanggestraften', Justitiële Verkenningen 2013, afl. 2, p. 120 -139; W.F. van Hattum, 'Van gratie naar herbeoordeling: Over de verkorting van de levenslange gevangenisstraf', DD 2017/25, afl. 47(4), p. 239-260 en W.F. van Hattum, 'De rechter, de minister en de levenslange gevangenisstraf', Trema 2013, afl. 7, p. 220-225 
van de Mens (hierna: EHRM). Sterker nog, de in het Caribische gebied geïntroduceerde periodieke toetsing van de levenslange gevangenisstraf na 20, dan wel 25 jaar, wordt door het EHRM geprezen. ${ }^{4}$ De met het Wetboek van Strafrecht ingevoerde tbs-regeling leidt nog wel tot problemen. Het probleem is echter eerder een praktisch dan een juridisch probleem. Er is nog geen kliniek beschikbaar waarbinnen de tbs-maatregel op een toereikende wijze kan worden ten uitvoer gelegd. ${ }^{5}$ In Aruba, in Curaçao en in het BES-gebied is de tbs al een enkele keer opgelegd. Uitvoeringswetgeving om de wettelijke mogelijkheid tot het opleggen van de tbs-maatregel praktische invulling te geven is reeds aangeboden en wordt momenteel in Curaçao behandeld. Bovendien zijn Aruba en Curaçao bezig met plannen om de beschikbare (psychiatrische) zorg in gevangenissen op Aruba en Curaçao te verbeteren. $\mathrm{Zij}$ zijn voornemens een gezamenlijke werkgroep te formeren om de mogelijkheid te onderzoeken tot het opzetten van een gemeenschappelijke faciliteit. ${ }^{6}$

\section{Regelgeving: van concordantie tot eenvormigheid}

Artikel 39 van het Statuut dwingt de landen van het Koninkrijk der Nederlanden de regelgeving op, onder meer om zoveel mogelijk op het gebied van het strafrecht en de strafvordering op overeenkomstige wijze aan te leveren. Een ingrijpende wijziging van de regelgeving, zoals in Nederland bijvoorbeeld het project Modernisering van Strafvordering en het herzien van het Wetboek van Strafvordering in het Caribisch gebied, betekent dat de landen binnen het Koninkrijk elkaar daarvan op de hoogte moeten brengen. Op die manier worden de overige landen in de gelegenheid gesteld om hun standpunt over die voorgenomen wijzigingen kenbaar te maken. ${ }^{7}$ Voor het strafrecht betekent dit dat onderlinge verschillen als uitgangspunt in het Caribisch gebied niet worden getolereerd. ${ }^{8}$ Daarvan kan worden afgeweken als het bijvoorbeeld gaat om de strafmaat die op een gedraging wordt gesteld of als het gaat om de inrichting van die regeling. Daarbinnen mag onderling worden afgeweken.

4. EHRM 26 april 2016, ECLI:CE:ECHR:2016:0426JUD001051110 (Murray $t$. Nederland).

5. A.D. Marchena-Slot, 'Perspectieven Post-Murray voor gedetineerden met een psychische stoornis in Curaçao', Strafblad 2019/18, afl. 2, p. 52-60.

6. Rapportage 2017 Internationale Mensenrechtenprocedures, Afdeling Internationaal Recht, Directie Juridische Zaken, Ministerie van Buitenlandse Zaken, Den Haag: 2017, p. 41

7. Artikel 39, tweede lid, Statuut.

8. Zie voor meer daarover L.J.J. Rogier, 'Concordantie in de Toekomst; meer eenvormigheid in het nieuwe bestel van het Caribische Koninkrijk?', in: H. de Doelder (red.), Strafrecht in de Antillen na '10-10-10, Nijmegen: Wolf Legal Publishers 2010, p. 97-107.
Voor het Wetboek van Strafvordering geldt hetzelfde principe. In het geval van een formele regeling als strafvordering is dat principe veel sterker. Dit betekent dat onderlinge verschillen veel minder getolereerd kunnen worden dan in het Wetboek van Strafrecht het geval is. Het minder tolerant zijn naar onderlinge verschillen staat in verband met de voorheen geldende 'Samenwerkingsregeling eenvormig procesrecht Nederlandse Antillen en Aruba' (hierna: samenwerkingsregeling). De samenwerkingsregeling kwam voort uit het Wetboek van Strafvordering van 5 november 1996 en is gepubliceerd in P.B. 1996, no. 164. Die regeling is op 1 oktober 1997 in werking getreden in de Nederlandse Antillen en Aruba. ${ }^{9} \mathrm{Na}$ het ontbinden van de Nederlandse Antillen op 10 oktober 2010 is deze regeling niet meer van toepassing. Daarvoor is als oorzaak aan te wijzen dat de 'Samenwerkingsregeling eenvormig procesrecht Aruba, Curaçao en Sint Maarten', die de 'Samenwerkingsregeling eenvormig procesrecht Nederlandse Antillen en Aruba' moest vervangen, in de landen (in het bijzonder Aruba) nog niet vastgesteld is. De Ministeriële Samenwerkingsraad, de instantie die wijzigingen in de eenvormige landsverordeningen dient vast te stellen, kan door het uitblijven daarvan nog niet functioneren.

Het principe van de eenvormigheid van wetgeving is dus in het strafprocesrecht veel sterker dan bij de strafrechtswetgeving. Dat laatste hangt samen met een tweetal factoren. Enerzijds is dat de interregionale samenwerking tussen de Caribische landen en anderzijds ligt de beoordeling van die regelgeving bij het Gemeenschappelijk Hof van Justitie en eventueel de Hoge Raad. Interregionale samenwerking neemt in het Caribisch gebied een prominente rol in. Dat hangt samen met het bestrijden van georganiseerde criminaliteit, die zich voornamelijk met drugshandel, mensenhandel en witwassen bezighoudt. De landen van het Koninkrijk die in de Cariben liggen zijn relatief klein van omvang. Dat betekent dat al snel sprake is van grensoverschrijdende criminaliteit. Wanneer elk land er een eigen Wetboek van Strafvordering op nahoudt met eigen normering en regelingen, leidt dat betrekkelijk snel tot het schenden van bepaalde regelingen. Daarnaast kan dit het zogenaamde 'forum-shoppen' in de hand werken. Dat betekent dat de opsporing op zoek gaat naar de regelgeving die de lichtste voorwaarden aan de inzet van zekere bevoegdheden stelt. Het land waar de minst zware eisen worden gesteld wordt dan het land waar de opsporing die bevoegdheid verzoekt. Met het oog op de rechtszekerheid voor de burgers van het Caribisch gebied lijkt dat in ieder geval geen wenselijke ontwikkeling.

Verweven met de interregionale factor is de factor van de toetsing in rechte. Uiteindelijk wordt het handelen van de opsporing door het Gemeenschappelijk Hof getoetst in rechte. Indien elk Caribisch land zijn eigen

9. De inwerkingtreding van de oorspronkelijke regeling is op grond van artikel 651, eerste lid, geregeld in Titel III, artikel IV, van de Invoeringslandsverordening wetboek van strafvordering (P.B. 1997, no. 237). 
regelgeving heeft op het gebied van het strafprocesrecht, worden onvermijdelijk fouten gemaakt. De rechter moet dan in een ruim aantal zaken beoordelen welk recht het toepasselijk recht is en vervolgens aan de hand van de specifieke bepalingen een beoordeling maken of de uitvoering van de opsporingsbevoegdheden conform die regelingen is geschied. Die beoordeling wordt complexer wanneer het onderzoek in meerdere landen in het Caribisch gebied is uitgevoerd. In geval van cassatie geldt ditzelfde voor de Hoge Raad. De Hoge Raad der Nederlanden, het Gemeenschappelijk Hof van Justitie van Aruba, Curaçao en Sint Maarten en van Bonaire, Sint Eustatius en Saba, de Gerechten in eerste aanleg, de advocatuur en de vervolgings- en opsporingsautoriteiten zijn alle gebaat bij de invoering van een gelijkluidend strafprocesrecht.

\section{Herziening Wetboek van Strafvordering}

In de Nederlandse Antillen en Aruba is het Wetboek van Strafvordering in werking getreden in 1997. Dat wetboek is rijp voor herziening. Daar bestaan een aantal redenen voor. De belangrijkste worden onder meer veroorzaakt door internationale regelgeving en rechtspraak. Daarbij kan worden gewezen op het EVRM en de uitspraken van het EHRM inzake de rechtsbijstand ( $\mathrm{Sal}$ $d u z$ en andere uitspraken), het Verdrag inzake drugssmokkel over zee en het cybercrimeverdrag. ${ }^{10}$ De voortschrijdende ontwikkeling van de techniek heeft andere wijzigingen noodzakelijk gemaakt. Dat betreft bijvoorbeeld het audiovisueel registreren van verhoren, maar ook nieuwe mogelijkheden tot het doen van onderzoek aan lichaamsmateriaal om DNA-profielen of seksueel overdraagbare aandoeningen vast te stellen. Andere redenen voor het herzien van de strafvordering waren de behoeften om bepaalde procedures te stroomlijnen en de mogelijkheid in te voeren dat de rechter-commissaris, als het hoger beroep al loopt, onderzoekshandelingen kan verrichten. Op een eerder moment heeft de behoefte aan het introduceren van bijzondere opsporingsbevoegdheden en andere procedures (het zogenaamde derdenbeslag) aanleiding gegeven tot het herzien van de strafprocesregeling. Die wijzigingen zijn echter al in een eerder stadium in gelijkluidende regelingen neergelegd in de strafproceswetgeving van de verschillende landen. ${ }^{11} \mathrm{Om}$ de strafprocesregelgeving te

10. Verdrag inzake de bestrijding van strafbare feiten verbonden met elektronische netwerken, Boedapest 23 november 2001, Trb. 2002, 18 en de verbetering daarvan Trb. 2004, 54

11. Afkondigingsblad van Aruba 2012, no. 10, Landsverordening van 8 maart 2012 houdende wijziging van het Wetboek van Strafvordering van Aruba ( $A B 1996$ no. 75) (regeling bijzondere opsporingsbevoegdheden en andere spoedeisende veranderingen); Afkondigingsblad van Sint Maarten 2012, no. 25, Landsverordening van de 30e augustus 2012 houdende wijziging van het Wetboek van Strafvordering (bijzondere opsporingsbevoegdheden en andere spoedeisende veranderingen) en Publicatieblad van Curaçao, 2012, no. 67, Landsverordening van de 18de oktober 2012 houdende wijziging van herzien is door de ministers van Justitie van de Nederlandse Antillen en Aruba een gezamenlijke Commissie Herziening van het Wetboek van Strafvordering ingesteld met als doelstelling de herziening van de bestaande regelgeving. $\mathrm{Na}$ de ontbinding van de Nederlandse Antillen op 10 oktober 2010 is de Commissie aangevuld. De aanvulling bestond uit leden die de BES, Curaçao en Sint Maarten vertegenwoordigen, deels ter vervanging van de leden van de Nederlands-Antilliaanse commissie. De leden van de oude en de vernieuwde commissie zijn vertegenwoordigers van de rechterlijke macht, het Openbaar Ministerie, de advocatuur, de politie, de reclassering, alsmede uit de wetenschap.

Binnen die Commissie, zowel in oude als in nieuwe vorm, is de kwestie van de concordantie of de eenvormigheid dan wel gelijkluidendheid uitvoerig besproken en bediscussieerd. Die discussie heeft de gezamenlijke Commissie Herziening van het Wetboek van Strafvordering tot het standpunt gebracht dat, ongeacht of wel of geen wettelijke verplichting bestaat die ertoe verplicht om eenvormige teksten op te stellen, met het oog op de bruikbaarheid en praktische uitvoerbaarheid een en dezelfde tekst dient te worden opgesteld voor alle gebruikers. Dat betekende wel dat in sommige bepalingen van het concept-Wetboek van Strafvordering enige noodzakelijke kunstgrepen moesten worden gemaakt. Dat is met name terug te zien in de eerste bepalingen van het Wetboek van Strafvordering waarin de betekenis van bepaalde begrippen wordt gedefinieerd. Het concept gaat ervan uit dat bij de Invoeringslandsverordening van het eenmaal aangenomen concept de bepalingen van de landsverordening uit 1997 geheel worden ingetrokken. Alle landen in het Caribisch gedeelte van het Koninkrijk spreken dan over 'Wetboek van Strafvordering' zonder daarbij te verwijzen naar hun eigen land. Dat dient het uitgangspunt dat het Wetboek van Strafvordering eenzelfde tekst gebruikt, te onderstrepen. Praktisch gezien hoeft er dan ook maar één wetboek te worden uitgegeven dat in alle landen kan worden gebruikt.

In oktober 2013 heeft de Commissie het resultaat van de werkzaamheden aangeboden aan de ministers van Justitie van de verschillende Landen in het Caribische gebied. De Ministeries van Justitie van de verschillende landen waren vervolgens aan zet. $\mathrm{Zij}$ dienden de concepten rijp te maken voor aanbieding en de teksten naar hun Raad van Advies te zenden. Dat proces heeft in de verschillende landen een andere tijdsduur gehad. Ook de Raden van Advies hebben hun eigen agenda's, ook afhankelijk van diverse politieke ontwikkelingen in de landen. Dat bracht mee dat de adviezen van de Raad van Advies van Aruba, Curaçao en Sint Maarten op verschillende momenten zijn uitgebracht.

Gedurende de tijd dat het Ministerie van Justitie de tekst voorbereidde en de tijd die de Raden van Advies

het Wetboek van Strafvordering (bijzondere opsporingsbevoegdheden en andere spoedeisende veranderingen). 
nodig had om tot een advies te komen, heeft de Commissie herziening Wetboek van Strafvordering niet stilgezeten. De concepten zijn in die tijd nog verder aangescherpt en aangepast. De twee voornaamste redenen daarvoor zijn gelegen in het verwerken van latere jurisprudentie in die regelgeving, het verbeteren van misslagen en eventuele wijzigingen als gevolg van voortschrijdend inzicht. Wijzigingen als gevolg van internationale verplichtingen met het oog op de bestrijding van terrorisme en de ontwikkelingen op het gebied van computercriminaliteit kunnen anderzijds worden genoemd als reden voor latere aanpassing. De bevoegdheid tot verrichten van heimelijk onderzoek in een geautomatiseerd werk (anders gezegd: hacken van geautomatiseerde werken door de opsporing), concept-artikel 177 ta was bijvoorbeeld in het in 2013 aangeboden concept nog niet opgenomen. De aanscherping van de terrorismebepalingen volgt uit het aanvullende protocol ${ }^{12}$ bij het Verdrag van de Raad van Europa ter voorkoming van terrorisme. ${ }^{13}$ De 'ernstige bezwaren' zijn onder meer als grond voor voorlopige hechtenis in geval van verdenking van terroristisch misdrijven vervallen. Dat dient de bestrijding van terrorisme te versterken.

Het verbeterd Wetboek van Strafvordering is aangeboden aan de Ministeries van Justitie van Aruba, Curaçao en Sint Maarten. De ministeries wijzigden vervolgens naar aanleiding van de uitgebrachte adviezen van de Raad van Advies van Aruba, de Raad van Advies van Curaçao en de Raad van Advies van Sint Maarten en de verbeterde concepten, de teksten van het Wetboek van Strafvordering. Opgemerkt moet worden dat de verscheidene adviezen van de Raden van Advies in een gelijkluidende tekst voor alle landen is verwerkt. Op die manier wordt voorkomen dat onderlinge verschillen ontstaan. De definitieve teksten kunnen naar de Staten van de afzonderlijke landen worden gezonden en daar behandeld worden. $\mathrm{Na}$ de aanvaarding van het voorstel door de Staten moet het nog wel worden ingevoerd. Dat geschiedt in de Caribische landen door middel van een Invoeringslandsverordening dan wel het opnemen van een artikel in het voorstel waarin de datum van inwerkingtreding van het voorstel, mits aangenomen door de Staten, wordt bepaald. De vormgeving van de invoering is thans nog niet duidelijk. De landen streven er in elk geval naar om de Landsverordening, bevattende de herziening van het Wetboek van Strafvordering, voor 1 januari 2020 in de Staten behandeld te hebben.

12. Aanvullend Protocol bij het Verdrag van de Raad van Europa ter voorkoming van terrorisme, Riga 22 oktober 2015, Trb. 2016, 180.

13. Europees Verdrag ter voorkoming van terrorisme, Warschau 16 mei 2005, Trb. 2006, 34.

\section{De belangrijkste wijzingen in het Wetboek van Strafvordering}

Zoals vermeld is het Wetboek van Strafvordering opgesteld op een zodanige wijze dat het kan worden toegepast in alle vier de Caribische landen. Dat wil zeggen dat het Wetboek eveneens in de BES-landen kan worden ingevoerd. De minister van Justitie en Veiligheid heeft het voornemen om in de BES-landen regelgeving gelijkluidend aan die van Aruba, Curaçao en Sint Maarten in te voeren uitdrukkelijk bevestigd. ${ }^{14}$ De invoering van die regeling is echter niet in de handen van het Ministerie van Justitie en Veiligheid in Nederland; het moet door de Staten-Generaal worden geaccordeerd.

Ten opzichte van het bestaande Wetboek van Strafvordering wordt in nieuwe regelingen een groot aantal veranderingen doorgevoerd. Deze paragraaf benoemt de belangrijkste wijzigingen die in het concept zijn opgenomen. In de memorie van toelichting bij het conceptWetboek van Strafvordering staat een meer uitgebreide bespreking en toelichting op die amendementen. ${ }^{15}$ Regels betreffende de processtukken in strafzaken worden in de nieuwe regeling aangepast. Duidelijk wordt dat de officier van justitie de samensteller van het procesdossier is en dat er een procedure voor klachten is opgenomen. ${ }^{16}$ De bepalingen over het verhoor van de verdachte door de politie zijn gewijzigd en voor slachtoffers en hun nabestaanden wordt een regeling ingevoerd waarin onder andere een spreekrecht wordt geïntroduceerd. ${ }^{17}$ In Titel IV van het tweede boek, maar ook elders, wordt een regeling van de deskundige opgenomen. Hierin wordt onder meer geregeld welke eisen aan een deskundigenrapport worden gesteld en is een mogelijkheid tot aanvullend of tegenonderzoek opgenomen. Een buitenlandse opsporingsambtenaar kan onder bepaalde omstandigheden, neergelegd in het volkenrecht, zelfstandig verdachten in de landen buiten heterdaad anhouden. Het strafrechtelijk kort geding ${ }^{18}$ is uitgebreid door vorderingen ten tijde van de executie- en uitleveringsfase en appèl in alle gevallen nadrukkelijk toe te laten. ${ }^{19}$ De regeling van het onderzoek aan lichaam en kleding is nader uitgeschreven in artikel 78 en de regeling van het afnemen en onderzoeken van lichaamsmateriaal met het oog op het vaststellen van een DNA-profiel dan wel de aanwezigheid van seksueel overdraagbare ziektes is herzien. ${ }^{20}$ Ophouden voor

14. Kamerstukken // 2018/19, 34976, 6, p. 2

15. H. de Doelder e.a. (red.), Caribisch Wetboek van Strafvordering. Concept, Oisterwijk: Wolf Legal Publishers 2013, p. 323-501.

16. Artikelen 4,50 a en passim concept-Caribisch WvSv.

17. Tweede boek, titel III, concept-Caribisch WvSv.

18. Zie hierover ook: P.A.M. Mevis, J.S. Nan \& S. Struijk, ‘Kort geding en strafrecht: huidige en toekomstige plaatsbepaling', in: R.J.N. Schlössels e.a. (red.), De burgerlijke rechter in het publiekrecht, Deventer: Wolters Kluwer 2015, p. 379-400

19. Artikel 43 concept-Caribisch Caribisch WvSv.

20. Artikel 235a e.v. concept-Caribisch WvSv. 
onderzoek kan, na invoering, drie uur langer duren vanwege het in te voeren recht op consultatie en de in te voeren mogelijk tot het identificeren van verdachten. ${ }^{21}$ De rechtspositie van een inverzekeringgestelde op een politiebureau wordt verbeterd, het Openbaar Ministerie krijgt wel het recht op te komen tegen negatieve besluiten over het voortzetten van de inverzekeringstelling. De thans in de Caribische landen geldende termijn van twee dagen en acht dagen na verlenging om iemand in verzekering te stellen wordt gewijzigd naar een termijn van drie dagen met een mogelijkheid tot verlenging met drie dagen. ${ }^{22}$ Zoals is vermeld, wordt ook de voorlopige hechtenis aangepast. In de regeling is een beperking van de gevallen en gronden voor voorlopige hechtenis aangebracht, maar die geldt niet voor terroristische misdrijven. Daar is juist sprake van een verruiming. Wanneer een verdachte is veroordeeld in eerste aanleg betekent dat eerder dat zijn vrijheid wordt ontnomen in afwachting van het hoger beroep. ${ }^{23}$ De bewaring krijgt een termijn van maximaal veertien dagen, in stede van de thans geldende acht dagen en verlenging met acht dagen. Gevangenhouding kan in een keer voor een maximum termijn van negentig dagen bevolen worden. ${ }^{24}$

Met de invoering wordt een ruimere mogelijkheid tot het in beslag nemen van voorwerpen ingevoerd. ${ }^{25}$ 'Doorzoeken' wordt net als in Nederland de gangbare term en 'huiszoeken' verdwijnt als begrip. Bovendien wordt het doorzoeken mogelijk gemaakt zonder lijfelijke aanwezigheid van de rechter-commissaris. Daarnaast is er een introductie van de 'bevriezing'. Mede in verband met de reeds ingevoerde bijzondere opsporingsbevoegdheden en de opkomst van digitale opsporingsmogelijkheden, is de beklagregeling sterk uitgebreid.

Net als in Nederland blijft het gerechtelijke vooronderzoek niet meer bestaan. Dat betekent dat aan de rechtercommissaris een lijdelijker en meer toezichthoudende rol wordt toegedicht. Voorafgaand aan het onderzoek ter terechtzitting wordt procespartijen de mogelijkheid geboden om onderzoekshandelingen aan de rechtercommissaris te verzoeken. Laatstgenoemde kan ook ambtshalve dergelijke handelingen vorderen. ${ }^{26}$ Hiernaast is de regeling met betrekking tot de bedreigde getuige belangrijk herzien en zijn de regelingen over kroongetuigen en afgeschermde getuigen in het wetboek opgenomen. ${ }^{27}$ Het beëdigen van getuigen voor het verhoor door de rechter-commissaris is ruimer geformuleerd en er bestaat na invoering een regeling om van journalisten te vorderen dat zij meewerken aan een getuigenverhoor. ${ }^{28}$
Een strakkere inrichting van het onderzoek ter zitting is in het wetboek opgenomen. ${ }^{29}$ Aan het bewijsrecht worden geen fundamentele wijzigingen aangebracht. De bestaande plicht tot motiveren van het vonnis blijft gehandhaafd en wordt uitgebreid als het gaat om, kort gesteld, het gebruik van anoniem afgelegde verklaringen, voor de bewezenverklaring van het ten laste gelegde. ${ }^{30}$ Een uitbreiding van de rechten van de benadeelde partij evenals een uitbreiding van de ontvankelijkheid van een benadeelde partij is in de herziene regeling opgenomen. In hoger beroep wordt zijn positie ook versterkt. Bij de rechtsmiddelen wordt een bepaling opgenomen die de rechter-commissaris na het instellen van hoger beroep de mogelijkheid geeft om op verzoek weer onderzoekshandelingen te kunnen verrichten. ${ }^{31}$ Een door het Openbaar Ministerie ingesteld appel kan door de procureur-generaal weer worden ingetrokken, althans de bevoegdheid daartoe wordt geintroduceerd in het Wetboek van Strafvordering. ${ }^{32}$ De herzieningsregeling is gewijzigd en uitgebreid in navolging van Nederland. De herziening ten nadele kan slechts worden toegepast bij de misdrijven moord en doodslag. ${ }^{33}$

Wijzigingen zijn ook gemaakt in de bepalingen betreffende de internationale rechtshulp. Feitelijke behandeling vindt plaats door het Openbaar Ministerie en de verlofprocedure bij het Hof is komen te vervallen. De procedure voor overdracht tenuitvoerlegging van strafvonnissen is uitgebreid en gewijzigd. ${ }^{34}$ Daarnaast is overdracht en overname van de gehele strafvervolging geregeld in de internationale rechtshulp. ${ }^{35}$ Verder is in de nieuwe regeling de mogelijkheid tot instellen van gemeenschappelijke onderzoeksteams eveneens opgenomen. $^{36}$

De onderwerpen tenuitvoerlegging en kosten worden in het laatste boek van de strafvordering behandeld. Zonder belangrijke inhoudelijke wijzingen is de gratieregeling daarin uitgeschreven. Wel wordt het aanwenden van opsporingsbevoegdheden, zoals geregeld in de Wet bijzondere opsporingsbevoegdheden, ter ondersteuning van de executie ingevoerd en hebben de betekeningsvoorschriften een lichte modernisering ondergaan. ${ }^{37}$ Als laatste kan worden genoemd dat voor de schadecompensatie een integrale regeling opgenomen is. Die procedure omvat zowel de vergoeding van schade geleden als gevolg van (on)rechtmatige toepassing van strafrechtelijke dwangmiddelen als de vergoeding van schade die de niet-veroordeelde verdachte voor zijn verdediging heeft moeten maken. ${ }^{38}$

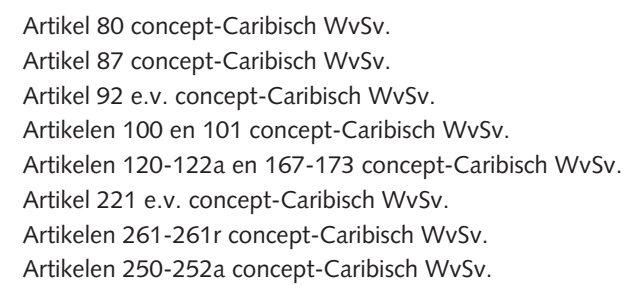

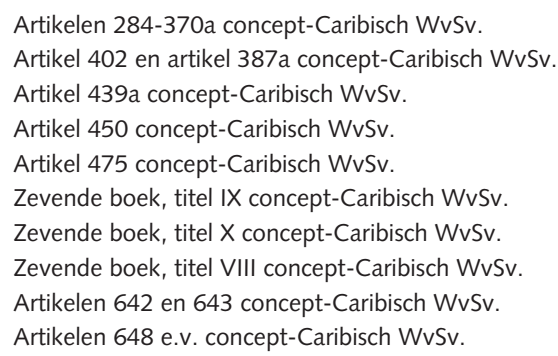




\section{Modernisering Strafvordering in Nederland en het Caribisch Wetboek van Strafvordering}

Net voordat het eerste concept-Caribisch Wetboek van Strafvordering aan de afzonderlijke ministers van Justitie werd aangeboden, werd in Nederland op 5 juli 2013 door de minister van Veiligheid en Justitie, minister Opstelten, een modernisering van het Nederlandse Wetboek van Strafvordering aangekondigd. ${ }^{39}$ De bestaande regeling, opgesteld in 1926, was volgens de minister van Veiligheid en Justitie door alle wijzigingen in de loop der tijd aangebracht, onsamenhangend geworden. Dat bevorderde volgens die minister niet altijd het strafproces. De modernisering had dan ook tot doel om een 'toekomstbestendig' wetboek te concipieren. Dat wetboek moet voorzien in een evenwichtig stelsel van rechtswaarborgen en bovendien een wetboek opleveren dat in praktijk werkbaar is voor professionals en burgers. ${ }^{40}$

Tot nu toe is in Nederland de herziening regeling Internationale samenwerking in strafzaken en de Tenuitvoerlegging in de toekomstige boeken zeven en acht angenomen. ${ }^{41}$ De inwerkingtreding van beide boeken laat nog op zich wachten. Vooralsnog is de verwachting dat de boeken in januari 2020 in werking treden. De geplande inwerkingtreding van de overige boeken van het gemoderniseerde Wetboek van Strafvordering heeft een vertraging opgelopen. Gepland was om die boeken na consultatie van de concepten en na verwerking van de adviezen, in januari 2019 naar de Afdeling advisering van de Raad van State te zenden voor advisering. ${ }^{42}$ Die planning is niet gehaald en de verzending naar de Raad van State staat nu voor 2020 op de agenda. Dat betekent dat de uiteindelijke inwerkingtreding ook met in elk geval een jaar is uitgesteld.

De modernisering van het Nederlandse Wetboek van Strafvordering bevat zonder enige twijfel voorstellen die de strafrechtsketen efficiënter maken en zelfs een verbetering daarvan inhouden. Het zou zinvol kunnen zijn om die ontwikkelingen af te wachten en voor zover nodig te implementeren in het Caribische strafprocesrecht. Het is echter aan te raden om dat pas te doen na het invoeren van het aangeleverde concept en die ontwikkeling niet af te wachten.

Hierboven is reeds gesteld dat de planning van de modernisering is uitgesteld. Invoering zal derhalve nog de nodige tijd in beslag nemen. Dat is een reden om die

39. Kamerstukken // 2014/15, 29279, 215, p. 1.

40. Zie hierover uitgebreid: P.A.M. Mevis, J.S. Nan, J.H.J. Verbaan \& P.C. Verloop (red.), Parlementaire geschiedenis modernisering Wetboek van Strafvordering (deel 0), Den Haag: Boom juridisch 2017.

41. Stb. 2017, 246 en Stb. 2017, 82.

42. Kamerstukken // 2017/18, 29279, 402, p. 1 ontwikkeling niet af te wachten. Daarnaast betekent afwachten dat de in Nederland voorgestelde wijzigingen op hun beurt weer moeten worden verwerkt in het Caribisch strafprocesrecht. Dat proces vergt de nodige inspanningen en zal dus ook een tijd duren. Tot slot moet er nog op worden gewezen dat het tijdsverloop tussen de presentatie van het eerste concept van het Caribisch Wetboek van Strafvordering en de daadwerkelijke behandeling van die regelgeving door de Staten de nodige tijd in beslag neemt. Gelet op het feit dat behandeling van het voorstel in de Staten nog niet heeft plaatsgehad, kan voorzichtig worden gesteld dat ook dat proces de nodige tijd in beslag zal nemen. Dat betekent dat de procespartijen, meer in het bijzonder de opsporing, met de bestaande regelgeving als vigerend kader moet werken. Die regelgeving schiet op sommige momenten tekort. Bovendien zullen internationale instanties, zoals bijvoorbeeld het CFATF, niet akkoord gaan met een zodanig uitstel. Zo concludeerde het CFATF in 2017 al over de regelgeving in Sint Maarten dat het land Sint Maarten 'is strongly recommended to prioritise the approval and entry into force of the $A M L / C F T$ legislation prior 2018 and provide the updated information regarding the compliance of the FATF Standards. ${ }^{43}$

Dat kan meebrengen dat het risico op ondermijning, dat wil zeggen het doordringen van de illegale onderwereld in de legale bovenwereld, toeneemt. Die ondermijning kan op haar beurt een reden zijn voor het internationale bankwezen om de landen van het Koninkrijk in de Caribische regio uit te sluiten van het internationale betalingsverkeer. Dat zou een ongelooflijke economische klap betekenen voor de landen in de Caribische regio. Een klap die bovendien kan worden voorkomen door, naast andere noodzakelijke maatregelen, in ieder geval de strafprocessuele regeling vóór 1 januari 2020 te behandelen.

\section{Tot slot}

De invoering van het concept-Wetboek van Strafvordering brengt, in samenhang met het reeds ingevoerde Wetboek van Strafrecht, de wetgeving in het Caribisch gebied van het Koninkrijk der Nederlanden weer op een internationaal anvaardbaar niveau. Bovendien leidt invoering tot een fundament voor het effectiever en efficiënter bestrijden van (georganiseerde) criminaliteit. De nieuwe regeling moet ook voor de uitvoerende instanties in de praktijk het werk eenvoudiger maken. Wetgeving is voortdurend aan verandering onderhevig. Het betreft soms kleine aanpassingen, maar soms majeure wetgeving operaties. In de Cariben heeft zo'n majeure operatie plaatsgevonden, hetgeen heeft geleid tot de aanbieding van een concept-Wetboek van Strafvordering in 2013. Inmiddels is in Nederland, 'het rijk in Europa', eveneens gestart met een majeure wetgevingsoperatie

43. CFATF, Report on Sint Maarten, 21 juni 2017, p. 3, cfatf-report-sintmaarten-may-2017-pp. 
'Modernisering Wetboek van Strafvordering'. Dat doet de vraag rijzen of dat proces in het Caribisch gebied niet moet worden afgewacht. Hierboven is betoogd dat langer wachten met de invoering van het Wetboek van Strafvordering in de Cariben niet aan te bevelen is, maar dat juist een snelle invoering wenselijk en noodzakelijk is. De landen zouden daar in verband met de noodzaak te voldoen aan internationale verplichtingen niet langer mee moeten talmen. Ook voor de invoering van het strafprocesrecht geldt het beginsel 'lites finiri oportet'. 